\title{
RECENT TRENDS OF MORTALITY FROM VIOLENCE
}

\author{
BY \\ W. J. MARTIN \\ Statistical Research Unit, of the Medical Research Council, London School of Hygiene and Tropical Medicine.
}

The causes of violent deaths have changed with the growth of civilization. In England the risk of being murdered or hanged is much smaller than three centuries ago when life was held to be cheaper, but in the last 150 years new and potent methods of killing have been introduced. With the development of industrialization new hazards arose from machinery, from railways, and from the internal combustion engine. In the last decades of the 19th century, there was an increasing awareness of the unnecessary waste of life from accidents in industry. The various risks in industry have been greatly reduced, but the more recent campaign against road accidents, although continuous and vigorous, has not met with any great success.

As a result of the measures taken, the death rate from accidents fell dramatically. In males, the death rate from accidents and negligence fell from 1,064 per million in 1861-70 to 496 in 1931-35, and in females it declined from 314 to 198 during this period. The death rate from accidents in coal mines fell from 96 per million in 1863-70 to forty in 1931-38. On the railways the death rate in males of 89 per million in $1871-80$ fell to only twenty in 1931-38. In males, deaths from accidental drowning were 214 per million in 1863-70 and 58 in 1931-38, and during this period the death rate in males from accidental burns and scalds fell from 109 to 29 per million. The death rate in males from all forms of suffocation was 73 in 1863-70, increased to 81 in $1891-1900$, and then fell steadily to twenty in 193138. The death rate from accidents due to horse vehicles was 124 per million in 1863-70, declined to 59 in 1901-10, and fell to five in 1931-38.

The very large fall in fatal accidents due to horse vehicles has been more than compensated for, however, by motor vehicles. The first deaths registered as due to motor cars were one male and one female in 1896 and the first motor-cycle deaths registered were two males in 1902 . From these small beginnings a terrific stream of deaths has resulted; in 1954 the numbers killed by motor vehicles were 3,289 males and 1,158 females, including 1,049 males and seventy females who died from motor-cycle accidents.

Aircraft have begun to be an important cause of violent death. In 1911 six deaths were registered, in 1921 the numbers rose to 64 , including 38 in the disaster to airship R38, and in 1954 the number of deaths was 225. The largest annual number of deaths from aircraft accidents was 311 in 1952.

The introduction of gas for domestic purposes provided another means of suicide that has become more frequent during the present century.

Although there was a large fall in the mortality from violence before 1939, the rate of decline has been much slower than that of the death rate from natural causes. As a result of this trend violence has become relatively more important as a cause of death; in 1861-71 deaths from violence formed $3 \cdot 4$ per cent. of all deaths and in 1931-39 the proportion was $4 \cdot 6$ per cent.

During the past 20 years there have been changes in the mortality from violence. The chief is the decline in mortality in males; in females the death rate has fluctuated about a fairly constant level. In 1935 the death rate per million was 743 for males and 345 for females. and in 1954 the rates were 593 and 358 respectively. The actual number of deaths was 14,479 males and 7,301 females in 1935 and 12,630 males and 8,239 females in 1954 .

The standardized death rates from violence during the past 90 years are shown in Table I. The death rates from all forms of violence have declined faster for males than for females. In males the rate in recent years is less than half the rate at the beginning of the period, while in females it is about two-thirds of its former level; consequently the death rate in males is now $2 \frac{1}{2}$ times that in females compared with $3 \frac{1}{3}$ times at the beginning of the period. The course of the standardized death rate for suicide has been 
different for the two sexes. In males the rate has fluctuated considerably, but in recent years has been slightly below the most favourable rates of the earlier years. In females, on the other hand, the rate increased from 1861 to 1940 , fell during the years $1941-45$, and has since risen slightly again to a level above that of the years 1861-1900. A fall in the

TABLE I

STANDARDIZED RATES PER MILLION FROM VIOLENCE (EXCLUDING WAR CASUALTIES) IN ENGLAND AND WALES, $1861-1954$

\begin{tabular}{|c|c|c|c|c|c|c|}
\hline \multirow{2}{*}{ Period } & \multicolumn{2}{|c|}{ Suicide } & \multicolumn{2}{|c|}{ Other Violence } & \multicolumn{2}{|c|}{ All Violence } \\
\hline & Males & Females & Males & Females & Males & Females \\
\hline $\begin{array}{c}1861-70 \\
1871-80 \\
1881-90 \\
1891-00 \\
1901-10 \\
1911-20 \\
1921-30 \\
1931-40 \\
1941 \\
1942 \\
1943 \\
1944 \\
1945 \\
1946 \\
1947 \\
1948 \\
1949 \\
1950 \\
1951 \\
1952 \\
1953 \\
1954\end{array}$ & $\begin{array}{r}105 \\
115 \\
128 \\
144 \\
157 \\
119 \\
138 \\
140 \\
96 \\
89 \\
95 \\
97 \\
95 \\
99 \\
95 \\
101 \\
101 \\
96 \\
94 \\
93 \\
101 \\
105\end{array}$ & $\begin{array}{l}35 \\
36 \\
39 \\
44 \\
47 \\
43 \\
52 \\
60 \\
44 \\
43 \\
44 \\
40 \\
46 \\
51 \\
51 \\
52 \\
50 \\
46 \\
46 \\
43 \\
48 \\
52\end{array}$ & $\begin{array}{r}1,064 \\
993 \\
829 \\
790 \\
670 \\
729 \\
523 \\
519 \\
702 \\
585 \\
530 \\
520 \\
506 \\
431 \\
447 \\
370 \\
383 \\
389 \\
423 \\
416 \\
402 \\
394\end{array}$ & $\begin{array}{l}314 \\
304 \\
284 \\
313 \\
282 \\
255 \\
201 \\
264 \\
254 \\
224 \\
200 \\
206 \\
202 \\
182 \\
184 \\
161 \\
155 \\
152 \\
156 \\
147 \\
153 \\
154\end{array}$ & $\begin{array}{r}1,169 \\
1,108 \\
957 \\
934 \\
827 \\
848 \\
661 \\
659 \\
798 \\
674 \\
625 \\
617 \\
601 \\
530 \\
542 \\
471 \\
484 \\
485 \\
517 \\
509 \\
503 \\
499\end{array}$ & $\begin{array}{l}349 \\
340 \\
323 \\
357 \\
329 \\
298 \\
253 \\
324 \\
298 \\
267 \\
244 \\
246 \\
248 \\
233 \\
235 \\
213 \\
205 \\
198 \\
202 \\
190 \\
201 \\
206\end{array}$ \\
\hline
\end{tabular}

suicide rate was recorded for both sexes during the two world wars, 1914-18 and 1940-45.

\section{ACCIDENTS}

Table II shows the age distribution of death rates from violence, excluding suicide and war casualities, by age and sex for the years 1941 to 1954 . The largest improvement in both sexes has been at ages 5 to 9 , where the death rate has fallen to one-third of the level of 1941. The death rates from birth to 4 years and from 10 to 14 years have fallen to less than onehalf of their initial level. The improvement for the age groups under 15 was similar for both sexes; at ages 25-74 the rate in males has been halved, while that in females has fallen by approximately onethird. The smallest rate of decline was in old age, 75 and over. Excluding old age, the smallest rate of improvement among males was at ages 15-19 and 20-24, the rates in 1954 being 72 and 82 per cent. respectively of the rates in 1941 . In childhood, the rate fell steadily during the period, but at older ages it declined to a minimum in the middle of the period with a tendency to rise in the more recent years. This happened in both sexes, but was more marked in males, especially in the age groups 15 to 40 , where the minimum was reached in 1948. At ages 20-24 the death rate fell from 741 per million in 1941 to 344 in 1948, rose to 684 in 1952, and declined to 608 in 1954.

TABLE II

DEATH RATES PER MILLION FROM VIOLENCE, (EXCLUDING SUICIDE AND WAR CASUALTIES) ENGLAND AND WALES, 1941-54

\begin{tabular}{|c|c|c|c|c|c|c|c|c|c|c|c|c|}
\hline \multirow{2}{*}{ Sex } & \multirow{2}{*}{ Year } & \multicolumn{11}{|c|}{ Age Group (yrs) } \\
\hline & & 0 & $5-$ & $10-$ & 15 & 20 & 25 & 35 & $45-$ & $55-$ & 65 & 75 and Over \\
\hline Males & $\begin{array}{l}1941 \\
1942 \\
1943 \\
1944 \\
1945 \\
1946 \\
1947 \\
1948 \\
1949 \\
1950 \\
1951 \\
1952 \\
1953 \\
1954\end{array}$ & $\begin{array}{l}839 \\
790 \\
720 \\
767 \\
736 \\
688 \\
664 \\
585 \\
547 \\
461 \\
489 \\
472 \\
418 \\
393\end{array}$ & $\begin{array}{l}523 \\
486 \\
481 \\
494 \\
498 \\
328 \\
381 \\
318 \\
299 \\
252 \\
261 \\
219 \\
217 \\
168\end{array}$ & $\begin{array}{l}348 \\
277 \\
263 \\
276 \\
297 \\
242 \\
225 \\
176 \\
193 \\
151 \\
182 \\
163 \\
149 \\
158\end{array}$ & $\begin{array}{l}553 \\
450 \\
417 \\
404 \\
459 \\
389 \\
388 \\
318 \\
383 \\
399 \\
403 \\
455 \\
409 \\
399\end{array}$ & $\begin{array}{l}741 \\
637 \\
546 \\
538 \\
623 \\
461 \\
476 \\
344 \\
438 \\
531 \\
639 \\
684 \\
641 \\
608\end{array}$ & $\begin{array}{l}648 \\
508 \\
480 \\
438 \\
393 \\
312 \\
343 \\
285 \\
284 \\
360 \\
406 \\
379 \\
366 \\
339\end{array}$ & $\begin{array}{l}584 \\
459 \\
418 \\
424 \\
348 \\
310 \\
332 \\
267 \\
294 \\
296 \\
308 \\
318 \\
303 \\
303\end{array}$ & $\begin{array}{l}696 \\
560 \\
496 \\
454 \\
388 \\
371 \\
414 \\
343 \\
338 \\
350 \\
368 \\
348 \\
360 \\
349\end{array}$ & $\begin{array}{r}1,000 \\
768 \\
651 \\
645 \\
556 \\
538 \\
517 \\
484 \\
450 \\
463 \\
483 \\
471 \\
469 \\
484\end{array}$ & $\begin{array}{r}1,403 \\
1,115 \\
946 \\
961 \\
863 \\
810 \\
815 \\
658 \\
650 \\
679 \\
707 \\
706 \\
771 \\
809\end{array}$ & $\begin{array}{l}3,168 \\
2,747 \\
2,333 \\
2,188 \\
2,204 \\
2,146 \\
2,304 \\
1,903 \\
2,063 \\
2,021 \\
2,272 \\
2,044 \\
2,332 \\
2,772\end{array}$ \\
\hline Females & $\begin{array}{l}1941 \\
1942 \\
1943 \\
1944 \\
1945 \\
1946 \\
1947 \\
1948 \\
1949 \\
1950 \\
1951 \\
1952 \\
1953 \\
1954\end{array}$ & $\begin{array}{l}623 \\
564 \\
521 \\
566 \\
561 \\
494 \\
503 \\
434 \\
387 \\
338 \\
350 \\
330 \\
318 \\
264\end{array}$ & $\begin{array}{r}247 \\
231 \\
180 \\
224 \\
209 \\
149 \\
162 \\
153 \\
128 \\
127 \\
97 \\
101 \\
95 \\
86\end{array}$ & $\begin{array}{r}105 \\
86 \\
98 \\
89 \\
94 \\
69 \\
63 \\
63 \\
63 \\
46 \\
45 \\
49 \\
59 \\
48\end{array}$ & $\begin{array}{r}116 \\
88 \\
82 \\
76 \\
78 \\
67 \\
70 \\
60 \\
67 \\
70 \\
78 \\
66 \\
62 \\
70\end{array}$ & $\begin{array}{r}97 \\
106 \\
79 \\
72 \\
74 \\
54 \\
54 \\
56 \\
65 \\
58 \\
68 \\
75 \\
65 \\
67\end{array}$ & $\begin{array}{l}82 \\
86 \\
72 \\
72 \\
71 \\
63 \\
57 \\
48 \\
40 \\
45 \\
47 \\
50 \\
50 \\
55\end{array}$ & $\begin{array}{l}90 \\
86 \\
75 \\
68 \\
69 \\
63 \\
65 \\
57 \\
51 \\
50 \\
59 \\
53 \\
60 \\
60\end{array}$ & $\begin{array}{r}144 \\
118 \\
102 \\
104 \\
98 \\
90 \\
103 \\
89 \\
85 \\
100 \\
94 \\
95 \\
105 \\
105\end{array}$ & $\begin{array}{l}283 \\
222 \\
186 \\
210 \\
187 \\
193 \\
195 \\
163 \\
171 \\
166 \\
167 \\
169 \\
183 \\
190\end{array}$ & $\begin{array}{l}793 \\
617 \\
533 \\
528 \\
537 \\
514 \\
536 \\
440 \\
452 \\
454 \\
481 \\
441 \\
501 \\
586\end{array}$ & $\begin{array}{l}3,253 \\
2,851 \\
2,582 \\
2,513 \\
2,455 \\
2,634 \\
2,593 \\
2,243 \\
2,374 \\
2,582 \\
2,743 \\
2,344 \\
2,636 \\
2,936\end{array}$ \\
\hline
\end{tabular}


The numerically important kinds of accidents for the years 1941-54 are shown in Table III. During the 14 years a substantial decline occurred in all forms of fatal accidents tabulated, except those from suffocation and poisoning, which have increased slightly, and those in females from falls. The death rate from motor vehicle accidents declined to a minimum in 1948 for males and in 1949 for females has reverted to the level of 9 years earlier. Deaths from falls also show a decline to a minimum in 1948 and a subsequent rise, but though the rates in males remained considerably below the initial level, in females the rate in 1954 was slightly above its 1941 level. The chance of a fatal accident from burns was the same for males and females in the early 1940s, but has fallen faster for males than for females; the chance of dying from accidental burns in 1954 was twice as large for females as for males. The morand then rose. As a result, of this rise the mortality

tality from accidental drowning has fallen considerably in males but has shown only a slight improvement in females. As a result the ratio has fallen, from 7 to 1 in 1941 to 4 to 1 in 1954 .

The death rates from the more important accidental causes are shown in Table IV by age and sex for three quinquennial periods. In males the death rates from accidental drowning have decreased by one-half in each age group under 65 ; in females the fall has been mainly confined to ages under 10 . The age trend of the rates is different in the two sexes. In each of the three quinquennia, the rate in males is high among pre-school children, rises at ages 5-9, falls at ages 10-14, and rises again at ages 15-19. With the exception of ages 75 and over, the chance of a drowning accident is highest at ages 5-9. In females, the death rate was largest at ages under 5 years, fell to a constant level in early middle life, and rose at the older ages.

TABLE III

DEATH RATES PER MILLION FROM ACCIDENTS, BY CAUSE, AND SEX, ENGLAND AND WALES, 1941 -1954

\begin{tabular}{|c|c|c|c|c|c|c|c|c|c|c|c|c|c|c|c|c|c|c|c|c|}
\hline \multirow[t]{2}{*}{ Year } & \multicolumn{2}{|c|}{ Railways } & \multicolumn{2}{|c|}{$\begin{array}{l}\text { Motor } \\
\text { Vehicle }\end{array}$} & \multicolumn{2}{|c|}{$\begin{array}{c}\text { Poisoned } \\
\text { by Solid } \\
\text { and Liquid } \\
\text { Substances }\end{array}$} & \multicolumn{2}{|c|}{$\begin{array}{c}\text { Poisoned } \\
\text { by Gases } \\
\text { and } \\
\text { Vapours }\end{array}$} & \multicolumn{2}{|c|}{ Falls } & \multicolumn{2}{|c|}{$\begin{array}{c}\text { Fire and } \\
\text { Explosion } \\
\text { of Com- } \\
\text { bustible } \\
\text { Material }\end{array}$} & \multicolumn{2}{|c|}{ Suffocation } & \multicolumn{2}{|c|}{ Drowning } & \multicolumn{2}{|c|}{ Others } & \multicolumn{2}{|c|}{$\underset{\text { Accidents }}{\text { All }}$} \\
\hline & Male & $\begin{array}{c}\text { Fe- } \\
\text { male }\end{array}$ & Male & $\begin{array}{c}\text { Fe- } \\
\text { male }\end{array}$ & Male & $\begin{array}{c}\mathrm{Fe}- \\
\text { male }\end{array}$ & Male & $\begin{array}{c}\text { Fe- } \\
\text { male }\end{array}$ & Male & $\begin{array}{c}\text { Fe- } \\
\text { male }\end{array}$ & Male & $\begin{array}{c}\text { Fe- } \\
\text { male }\end{array}$ & Male & $\begin{array}{c}\text { Fe- } \\
\text { male }\end{array}$ & Male & $\begin{array}{c}\text { Fe- } \\
\text { male }\end{array}$ & Male & $\begin{array}{c}\mathrm{Fe}- \\
\text { male }\end{array}$ & Male & $\begin{array}{c}\text { Fe- } \\
\text { male }\end{array}$ \\
\hline $\begin{array}{l}1941 \\
1942 \\
1943 \\
1944 \\
1945 \\
1946 \\
1947 \\
1948 \\
1949 \\
1950 \\
1951 \\
1952 \\
1953 \\
1954\end{array}$ & $\begin{array}{l}26 \\
26 \\
27 \\
28 \\
25 \\
22 \\
23 \\
17 \\
16 \\
16 \\
14 \\
18 \\
16 \\
12\end{array}$ & $\begin{array}{l}2 \\
2 \\
3 \\
3 \\
3 \\
3 \\
2 \\
3 \\
1 \\
2 \\
1 \\
3 \\
1 \\
1\end{array}$ & $\begin{array}{l}281 \\
208 \\
165 \\
178 \\
158 \\
153 \\
147 \\
128 \\
141 \\
151 \\
161 \\
149 \\
158 \\
161\end{array}$ & $\begin{array}{l}74 \\
56 \\
46 \\
55 \\
49 \\
47 \\
47 \\
44 \\
41 \\
46 \\
49 \\
42 \\
45 \\
51\end{array}$ & $\begin{array}{l}5 \\
5 \\
4 \\
4 \\
5 \\
5 \\
5 \\
6 \\
5 \\
5 \\
6 \\
7 \\
6 \\
7\end{array}$ & $\begin{array}{l}4 \\
3 \\
2 \\
3 \\
4 \\
4 \\
5 \\
4 \\
4 \\
6 \\
6 \\
6 \\
7 \\
7\end{array}$ & $\begin{array}{r}12 \\
9 \\
8 \\
10 \\
13 \\
10 \\
11 \\
10 \\
11 \\
10 \\
12 \\
12 \\
15 \\
15\end{array}$ & $\begin{array}{r}6 \\
6 \\
6 \\
7 \\
9 \\
10 \\
12 \\
9 \\
10 \\
11 \\
13 \\
13 \\
14 \\
17\end{array}$ & $\begin{array}{r}145 \\
127 \\
118 \\
107 \\
103 \\
88 \\
94 \\
78 \\
81 \\
74 \\
86 \\
79 \\
84 \\
99\end{array}$ & $\begin{array}{l}136 \\
120 \\
114 \\
111 \\
110 \\
110 \\
110 \\
100 \\
105 \\
113 \\
117 \\
105 \\
123 \\
141\end{array}$ & $\begin{array}{r}44 \\
41 \\
32 \\
31 \\
27 \\
20 \\
27 \\
13 \\
9 \\
9 \\
15 \\
13 \\
10 \\
10\end{array}$ & $\begin{array}{l}43 \\
39 \\
32 \\
32 \\
31 \\
27 \\
27 \\
20 \\
16 \\
16 \\
19 \\
19 \\
16 \\
19\end{array}$ & $\begin{array}{l}24 \\
24 \\
24 \\
27 \\
29 \\
30 \\
34 \\
26 \\
25 \\
23 \\
23 \\
22 \\
19 \\
23\end{array}$ & $\begin{array}{l}15 \\
13 \\
11 \\
16 \\
15 \\
18 \\
21 \\
17 \\
16 \\
14 \\
14 \\
13 \\
13 \\
13\end{array}$ & $\begin{array}{l}75 \\
59 \\
60 \\
63 \\
65 \\
44 \\
50 \\
39 \\
40 \\
36 \\
36 \\
34 \\
34 \\
30\end{array}$ & $\begin{array}{r}11 \\
10 \\
11 \\
10 \\
11 \\
11 \\
10 \\
11 \\
8 \\
9 \\
9 \\
8 \\
8 \\
8\end{array}$ & $\begin{array}{r}159 \\
139 \\
139 \\
129 \\
113 \\
96 \\
92 \\
85 \\
90 \\
97 \\
98 \\
97 \\
94 \\
92\end{array}$ & $\begin{array}{l}20 \\
22 \\
22 \\
18 \\
21 \\
15 \\
18 \\
14 \\
21 \\
16 \\
17 \\
17 \\
22 \\
15\end{array}$ & $\begin{array}{l}771 \\
638 \\
577 \\
577 \\
538 \\
468 \\
483 \\
402 \\
418 \\
421 \\
451 \\
431 \\
436 \\
449\end{array}$ & $\begin{array}{l}311 \\
271 \\
247 \\
255 \\
253 \\
245 \\
252 \\
222 \\
222 \\
233 \\
245 \\
226 \\
249 \\
272\end{array}$ \\
\hline
\end{tabular}

DEATH RATES PER MILLION FROM CERTAIN ACCIDE@ిTS,

\begin{tabular}{|c|c|c|c|c|c|c|c|c|c|c|c|}
\hline \multirow{3}{*}{$\begin{array}{l}\text { Type of } \\
\text { Accident }\end{array}$} & \multirow{3}{*}{ Quinquennium } & \multirow{2}{*}{\multicolumn{2}{|c|}{0}} & & & & & & & & OAge \\
\hline & & & & \multicolumn{2}{|c|}{ 5- } & \multicolumn{2}{|c|}{10} & \multicolumn{2}{|c|}{ 15- } & \multicolumn{2}{|c|}{$20-$} \\
\hline & & Male & Female & Male & Female & Male & Female & Male & Female & Male & Femân \\
\hline Drowning & $\begin{array}{r}1940-44 \\
1945-49 \\
1950-54 \\
\end{array}$ & $\begin{array}{l}92 \\
75 \\
49 \\
\end{array}$ & $\begin{array}{l}32 \\
24 \\
18 \\
\end{array}$ & $\begin{array}{r}120 \\
96 \\
63 \\
\end{array}$ & $\begin{array}{r}14 \\
13 \\
8 \\
\end{array}$ & $\begin{array}{l}64 \\
53 \\
31 \\
\end{array}$ & $\begin{array}{r}9 \\
11 \\
6 \\
\end{array}$ & $\begin{array}{l}69 \\
68 \\
42 \\
\end{array}$ & $\begin{array}{l}4 \\
7 \\
4 \\
\end{array}$ & $\begin{array}{l}71 \\
41 \\
29 \\
\end{array}$ & $\begin{array}{l}5 \\
\text { No } \\
30\end{array}$ \\
\hline Falls & $\begin{array}{l}1940-44 \\
1945-49 \\
1950-54\end{array}$ & $\begin{array}{l}38 \\
28 \\
17\end{array}$ & $\begin{array}{l}24 \\
16 \\
12\end{array}$ & $\begin{array}{l}35 \\
25 \\
12\end{array}$ & $\begin{array}{r}13 \\
7 \\
4\end{array}$ & $\begin{array}{l}26 \\
22 \\
14\end{array}$ & $\begin{array}{l}7 \\
5 \\
2\end{array}$ & $\begin{array}{l}46 \\
32 \\
24\end{array}$ & $\begin{array}{l}4 \\
5 \\
2\end{array}$ & $\begin{array}{l}62 \\
36 \\
32 \\
\end{array}$ & $\begin{array}{l}50 \\
40 \\
3\end{array}$ \\
\hline Fire & $\begin{array}{r}1940-44 \\
1945-49 \\
1950-54 \\
\end{array}$ & $\begin{array}{r}155 \\
61 \\
13 \\
\end{array}$ & $\begin{array}{r}135 \\
70 \\
28 \\
\end{array}$ & $\begin{array}{r}25 \\
11 \\
6 \\
\end{array}$ & $\begin{array}{l}53 \\
31 \\
19 \\
\end{array}$ & $\begin{array}{l}8 \\
5 \\
3 \\
\end{array}$ & $\begin{array}{r}20 \\
9 \\
7 \\
\end{array}$ & $\begin{array}{r}12 \\
5 \\
3 \\
\end{array}$ & $\begin{array}{r}13 \\
4 \\
4 \\
\end{array}$ & $\begin{array}{r}12 \\
2 \\
5 \\
\end{array}$ & . \\
\hline Motor Vehicles & $\begin{array}{r}1940-44 \\
1945-49 \\
1950-54\end{array}$ & $\begin{array}{r}145 \\
112 \\
90\end{array}$ & $\begin{array}{l}92 \\
64 \\
52\end{array}$ & $\begin{array}{l}246 \\
182 \\
104\end{array}$ & $\begin{array}{r}119 \\
90 \\
54\end{array}$ & $\begin{array}{r}114 \\
87 \\
64\end{array}$ & $\begin{array}{l}41 \\
32 \\
21\end{array}$ & $\begin{array}{l}161 \\
145 \\
201\end{array}$ & $\begin{array}{l}43 \\
32 \\
38\end{array}$ & $\begin{array}{l}241 \\
210 \\
337\end{array}$ & $\begin{array}{l}3900 \\
240 \\
340 \\
0\end{array}$ \\
\hline
\end{tabular}


During the 15 years fatal falls have declined in every age group except in old age (75 and over), where the rates in 1950-54 exceeded those in 1945-49. The rate in males was considerably in excess of that in females in each age group up to age 65 . The death rate in females slightly exceeded that in males at ages 65-70 and was considerably above it at ages 75 and over. Since 1949, the place of occurrence has been tabulated, and the percentage distribution of 8,974 fatal falls in males and 13,657 in females during 1950-54 is shown in Table V. The differences between the sexes are partly due to the difference in occupational risk. Fatal falls from one level to another occurred at work in 50.4 per cent. of accidents in males and in only $1 \cdot 1$ per cent, in females.

TABLE V

DEATHS FROM FALLS, BY SEX

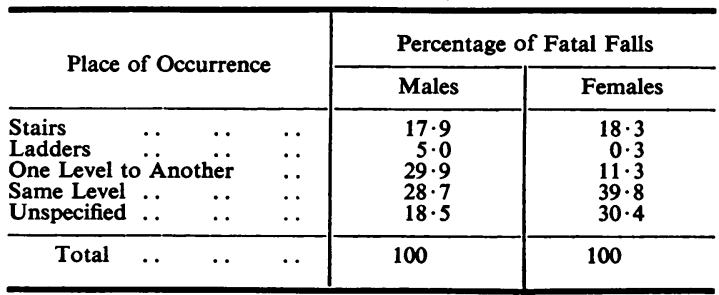

The number of fatal falls at home by age and sex is shown in Table VI for the quinquennium 1950-54. There is a considerable difference between the sexes; in each age group females have a larger proportion of fatal accidents at home than males, but the actual number of fatal accidents at home is larger for males in each age group up to age 45. At ages over 65 females have rather more than $2 \frac{1}{2}$ times as many fatal falls at home as males. The proportion of fatal falls that occurred at home at ages 65 and over was 81 per cent. for males and 93 per cent. for females.
TABLE VI

DEATHS FROM ACCIDENTAL FALLS, BY AGE AND SEX, ENGLAND AND WALES, 1950-54

\begin{tabular}{|c|c|c|c|c|c|c|c|}
\hline \multirow{3}{*}{ Sex } & \multirow{3}{*}{.. } & \multicolumn{3}{|c|}{ Males } & \multicolumn{3}{|c|}{ Females } \\
\hline & & \multirow{2}{*}{$\begin{array}{l}\text { Total } \\
\text { Num- } \\
\text { ber } \\
\text { of } \\
\text { Falls }\end{array}$} & \multicolumn{2}{|c|}{$\begin{array}{l}\text { Falls at } \\
\text { Home or in } \\
\text { Residential } \\
\text { Institutions }\end{array}$} & \multirow{2}{*}{$\begin{array}{l}\text { Total } \\
\text { Num- } \\
\text { ber } \\
\text { of } \\
\text { Falls }\end{array}$} & \multicolumn{2}{|c|}{$\begin{array}{l}\text { Falls at } \\
\text { Home or in } \\
\text { Residential } \\
\text { Institutions }\end{array}$} \\
\hline & & & No. & $\begin{array}{c}\text { Per } \\
\text { Cent. }\end{array}$ & & No. & $\begin{array}{c}\text { Per } \\
\text { Cent. }\end{array}$ \\
\hline \multirow{6}{*}{ Age } & 0 & 155 & 117 & $75 \cdot 5$ & 103 & 82 & $79 \cdot 6$ \\
\hline & $5-$ & 208 & 41 & $19 \cdot 7$ & 54 & 14 & $25 \cdot 9$ \\
\hline & 15 & 1,381 & 242 & $17 \cdot 5$ & 164 & 98 & $59 \cdot 8$ \\
\hline & $45-$ & 1,568 & 571 & $36 \cdot 4$ & 799 & 619 & $77 \cdot 5$ \\
\hline & 65 and Over & 5,662 & 4,240 & 74.9 & 12,537 & 10,835 & $86 \cdot 4$ \\
\hline & Total & 8,974 & 5,211 & $58 \cdot 1$ & 13,657 & 11,648 & $85 \cdot 3$ \\
\hline
\end{tabular}

The risk of a fatal burn (Table IV) has fallen during the 15 years in each age group in both sexes, the greatest improvement being in childhood. The risk of a fatal burn is much larger among females under 10 years of age and over 65 years than among males, and the fall in the death rate in childhood has been greater among boys than among girls. At ages $0-4$ the rate in girls was slightly below that in boys in 1940-44; in 1950-54, however, it was over twice that in boys. At ages 5-9 the rate in girls was higher than in boys; in a ratio rising from 2 to 3 in the 15 years.

In each age group in both sexes the death rate from motor vehicle accidents (Table IV) was lower in 1945-49 than in 1940-44, but rose again in 1950-54 in each male age group over age 15 . This rise was most marked in the age groups 15-19, 20-24, and $25-29$; in the first two age groups the male rate for $1950-54$ was considerably above the rate for $1940-44$.

BY AGE AND SEX, ENGLAND AND WALES, 1940-1954

Group (yrs)

\begin{tabular}{|c|c|c|c|c|c|c|c|c|c|c|c|c|c|}
\hline \multicolumn{2}{|c|}{ 25- } & \multicolumn{2}{|c|}{$35-$} & \multicolumn{2}{|c|}{$45-$} & \multicolumn{2}{|c|}{$55-$} & \multicolumn{2}{|c|}{$65-$} & \multicolumn{2}{|c|}{$\begin{array}{c}75 \\
\text { and Over }\end{array}$} & \multicolumn{2}{|c|}{ Total } \\
\hline Male & Female & Male & Female & Male & Female & Male & Female & Male & Female & Male & Female & Male & Female \\
\hline $\begin{array}{l}42 \\
21 \\
16 \\
\end{array}$ & $\begin{array}{l}6 \\
4 \\
3 \\
\end{array}$ & $\begin{array}{l}37 \\
19 \\
17 \\
\end{array}$ & $\begin{array}{l}6 \\
6 \\
5\end{array}$ & $\begin{array}{l}49 \\
28 \\
24\end{array}$ & $\begin{array}{r}10 \\
10 \\
9\end{array}$ & $\begin{array}{l}64 \\
41 \\
37\end{array}$ & $\begin{array}{l}13 \\
13 \\
11\end{array}$ & $\begin{array}{l}77 \\
65 \\
62 \\
\end{array}$ & $\begin{array}{l}15 \\
15 \\
17\end{array}$ & $\begin{array}{l}80 \\
86 \\
93\end{array}$ & $\begin{array}{l}14 \\
13 \\
17\end{array}$ & $\begin{array}{l}64 \\
46 \\
35\end{array}$ & $\begin{array}{r}11 \\
10 \\
9\end{array}$ \\
\hline $\begin{array}{l}69 \\
36 \\
31\end{array}$ & $\begin{array}{l}6 \\
4 \\
3\end{array}$ & $\begin{array}{l}69 \\
45 \\
36\end{array}$ & $\begin{array}{r}12 \\
5 \\
5\end{array}$ & $\begin{array}{r}101 \\
58 \\
51\end{array}$ & $\begin{array}{l}30 \\
15 \\
13\end{array}$ & $\begin{array}{r}179 \\
98 \\
79\end{array}$ & $\begin{array}{l}94 \\
57 \\
46\end{array}$ & $\begin{array}{l}383 \\
232 \\
235\end{array}$ & $\begin{array}{l}398 \\
261 \\
245\end{array}$ & $\begin{array}{l}1,608 \\
1,228 \\
1,305\end{array}$ & $\begin{array}{l}2,340 \\
1,887 \\
2,029\end{array}$ & $\begin{array}{r}139 \\
93 \\
87\end{array}$ & $\begin{array}{l}129 \\
107 \\
120\end{array}$ \\
\hline $\begin{array}{r}14 \\
5 \\
5\end{array}$ & $\begin{array}{l}9 \\
5 \\
2\end{array}$ & $\begin{array}{l}9 \\
5 \\
8\end{array}$ & $\begin{array}{l}9 \\
4 \\
3 \\
\end{array}$ & $\begin{array}{r}10 \\
6 \\
9\end{array}$ & $\begin{array}{r}16 \\
9 \\
6\end{array}$ & $\begin{array}{l}18 \\
12 \\
13\end{array}$ & $\begin{array}{l}31 \\
19 \\
13\end{array}$ & $\begin{array}{l}48 \\
27 \\
21\end{array}$ & $\begin{array}{l}77 \\
48 \\
40\end{array}$ & $\begin{array}{l}160 \\
115 \\
109\end{array}$ & $\begin{array}{l}254 \\
210 \\
161\end{array}$ & $\begin{array}{l}32 \\
16 \\
12\end{array}$ & $\begin{array}{l}38 \\
25 \\
18\end{array}$ \\
\hline $\begin{array}{l}192 \\
121 \\
160\end{array}$ & $\begin{array}{l}30 \\
17 \\
19\end{array}$ & $\begin{array}{r}154 \\
95 \\
109\end{array}$ & $\begin{array}{l}27 \\
20 \\
20\end{array}$ & $\begin{array}{l}180 \\
103 \\
110\end{array}$ & $\begin{array}{l}41 \\
27 \\
32\end{array}$ & $\begin{array}{l}271 \\
146 \\
151\end{array}$ & $\begin{array}{l}66 \\
52 \\
51\end{array}$ & $\begin{array}{l}411 \\
234 \\
234\end{array}$ & $\begin{array}{r}120 \\
97 \\
98\end{array}$ & $\begin{array}{l}662 \\
443 \\
484\end{array}$ & $\begin{array}{l}188 \\
165 \\
194\end{array}$ & $\begin{array}{l}215 \\
142 \\
154\end{array}$ & $\begin{array}{l}59 \\
45 \\
46\end{array}$ \\
\hline
\end{tabular}


Deaths of motor cyclists contributed largely to the excess in these age groups. The distribution by type of accident in 1950-54 for ages 15-19 and 20-24 is shown in Table VII. The absence of the numbers exposed to risk in these eight groups makes impossible any inferences about the relative risks of different types of accident. For example, nothing can be inferred about the relative danger of pedal cycles in the two age groups, although the number of pedal cyclists killed at ages 15-19 was twice the number at ages 20-24; the younger age group may contain many more users of pedal cycles than the older, where, perhaps, pedal cycles have been replaced by motor cycles or motor cars.

TABLE VII

DEATHS OF YOUNG ADULT MALES FROM ROAD ACCIDENTS

\begin{tabular}{|c|c|c|c|c|c|}
\hline \multirow{3}{*}{\multicolumn{2}{|c|}{ Road Users }} & \multicolumn{4}{|c|}{ Males } \\
\hline & & \multicolumn{2}{|c|}{ Ages 15-19 } & \multicolumn{2}{|c|}{ Ages 20-24 } \\
\hline & & No. & Per Cent. & No. & Per Cent. \\
\hline $\begin{array}{ll}\text { Pedestrians .. } & \ldots \\
\text { Pedal Cyclists } & \ldots \\
\text { Riders or Passengers } \\
\text { Motor Cycles } \\
\text { All Others } & \ldots \\
\text { All }\end{array}$ & $\begin{array}{l}\ddot{ } \\
\ddot{\text { on }} \\
\cdots \\
\cdots\end{array}$ & $\begin{array}{l}108 \\
280 \\
680 \\
149\end{array}$ & $\begin{array}{r}9 \cdot 4 \\
24 \cdot 5 \\
53 \cdot 1 \\
13 \cdot 0\end{array}$ & $\begin{array}{r}120 \\
136 \\
1,516 \\
300\end{array}$ & $\begin{array}{r}5 \cdot 8 \\
6 \cdot 6 \\
73 \cdot 2 \\
14 \cdot 4\end{array}$ \\
\hline Total .. & . & 1,145 & $100 \cdot 0$ & 2,072 & $100 \cdot 0$ \\
\hline
\end{tabular}

Lack of adult supervision plays an important part in accidental deaths among pre-school children. The variation in the death rates from different types of accidents during the first years of life are shown in Table VIII for the years 1950-54. Boys had a higher death rate at each age and for every cause than girls, except for burns and scalds. In boys, the death rate from burns and scalds rose to a maximum at age 1 and fell steadily to one-quarter of this level by age 4-5. In girls, it was at a maximum at age 2 and then fell slowly, so that the death rate of girls at age 4-5 was three times that of boys. The death rate from drowning was highest at age 2 , its subsequent fall being more rapid for girls than for boys. The death rate from falls was fairly constant during the first
4 years of life and then fell by one-half in the fifth year. In boys, the risk of a fatal motor vehicle accident increased throughout the first five years of life; in girls, it fell slightly at ages 4-5. Of the deaths from suffocation during the first year of life, 50 per cent. were due to inhalation or ingestion of food, and 46 per cent. to suffocation in cot or cradle. Accidental poisoning arises from a wide variety of substances. Swinscow (1953), in a detailed analysis of deaths from accidental poisoning among children aged 1-4 during 1931-49, found that slightly over one-half of the deaths were due to medicaments and about one-quarter to household poisons. About one quarter of the medicaments were liniments of various kinds, and the remainder were mainly preparations which were regarded as harmless to adults even in large doses. Household poisons included rat poison, insecticides, turpentine, etc., but excluded disinfectants, which accounted for about 7 per cent. of the deaths.

\section{SUICIDE}

The death rates from suicide by age and sex for recent years are shown in Table IX (opposite). In males, the suicide rate steadily increased throughout life, but, in females, it fell sharply at ages 75 and over to below the rates for ages $45-64$ and $65-74$. The largest difference between the death rates of the two sexes is seen at ages 75 and over. During the past 14 years changes have occurred in the age and sex distribution of these deaths. The suicide rate has declined for both sexes under the age of 25 years but has increased at ages 45 and over. At ages 15-19 and 20-24 this fall has been less for females than for males. At the beginning of the period, the rate in males in these age groups was 3 to 4 times greater than that in females; in the last years it was $2 \frac{1}{2}$ to 3 times greater. At the other extreme of life, the rate has risen faster in females than in males. At ages $65-74$, the ratio fell from 3 to 2 during the period. At ages 75 and over, the rate in males was from 5 to 6 times that in females at the beginning of the period and about $3 \frac{1}{2}$ times at the end.

TABLE VIII

DEATH RATE PER MILLION FROM ACCIDENTS AMONG CHILDREN UNDER 5 IN ENGLAND AND WALES, BY SEX, 1950-54

\begin{tabular}{|c|c|c|c|c|c|c|c|c|c|c|}
\hline \multirow{3}{*}{ Cause } & \multicolumn{10}{|c|}{ Age (yrs) } \\
\hline & \multicolumn{2}{|c|}{0} & \multicolumn{2}{|c|}{$1-$} & \multicolumn{2}{|c|}{2} & \multicolumn{2}{|c|}{3} & \multicolumn{2}{|c|}{$4-5$} \\
\hline & Male & Female & Male & Female & Male & Female & Male & Female & Male & Female \\
\hline $\begin{array}{ll}\text { Scalds and Burns } & \ldots \\
\text { Drowning } & \ldots \\
\text { Falling, Crushing } & \ldots \\
\text { Motor Vehicles } & \ldots \\
\text { Suffocation.. } & \ldots \\
\text { Poisoning } & \ldots\end{array}$ & $\begin{array}{r}28 \\
7 \\
23 \\
8 \\
858 \\
8\end{array}$ & $\begin{array}{r}29 \\
7 \\
13 \\
4 \\
641 \\
7\end{array}$ & $\begin{array}{l}52 \\
44 \\
26 \\
61 \\
49 \\
43\end{array}$ & $\begin{array}{l}47 \\
22 \\
16 \\
40 \\
35 \\
28\end{array}$ & $\begin{array}{r}33 \\
73 \\
23 \\
117 \\
11 \\
14\end{array}$ & $\begin{array}{r}51 \\
30 \\
17 \\
73 \\
8 \\
10\end{array}$ & $\begin{array}{r}27 \\
67 \\
20 \\
124 \\
4 \\
12\end{array}$ & $\begin{array}{r}48 \\
19 \\
13 \\
76 \\
4 \\
4\end{array}$ & $\begin{array}{r}14 \\
53 \\
13 \\
132 \\
3 \\
4\end{array}$ & $\begin{array}{r}42 \\
13 \\
6 \\
64 \\
1 \\
6\end{array}$ \\
\hline
\end{tabular}


TABLE IX

DEATH RATES PER MILLION FROM SUICIDE, BY AGE AND SEX, ENGLAND AND WALES, 1941-1954

\begin{tabular}{|c|c|c|c|c|c|c|c|c|c|c|}
\hline \multirow{2}{*}{ Sex } & \multirow{2}{*}{ Year } & \multicolumn{9}{|c|}{ Age Group (yrs) } \\
\hline & & 10 & $15-$ & 20 & 25 & 35 & 45 & $65-$ & 75 and Over & All Ages \\
\hline Males & $\begin{array}{l}1941 \\
1942 \\
1943 \\
1944 \\
1945 \\
1946 \\
1947 \\
1948 \\
1949 \\
1950 \\
1951 \\
1952 \\
1953 \\
1954\end{array}$ & $\begin{array}{l}3 \\
3 \\
2 \\
3 \\
4 \\
5 \\
3 \\
2 \\
1 \\
1 \\
6 \\
1 \\
1 \\
3\end{array}$ & $\begin{array}{l}37 \\
42 \\
38 \\
34 \\
34 \\
30 \\
36 \\
29 \\
33 \\
35 \\
29 \\
40 \\
33 \\
30\end{array}$ & $\begin{array}{r}81 \\
77 \\
104 \\
111 \\
82 \\
71 \\
69 \\
76 \\
62 \\
64 \\
61 \\
64 \\
80 \\
69\end{array}$ & $\begin{array}{r}100 \\
96 \\
95 \\
108 \\
110 \\
93 \\
85 \\
83 \\
81 \\
72 \\
80 \\
81 \\
91 \\
96\end{array}$ & $\begin{array}{l}130 \\
117 \\
140 \\
126 \\
116 \\
145 \\
114 \\
131 \\
134 \\
124 \\
120 \\
120 \\
127 \\
147\end{array}$ & $\begin{array}{l}232 \\
211 \\
219 \\
226 \\
226 \\
244 \\
254 \\
269 \\
278 \\
265 \\
249 \\
247 \\
263 \\
278\end{array}$ & $\begin{array}{l}374 \\
331 \\
348 \\
332 \\
352 \\
391 \\
383 \\
469 \\
422 \\
416 \\
412 \\
390 \\
412 \\
430\end{array}$ & $\begin{array}{l}414 \\
366 \\
314 \\
395 \\
421 \\
465 \\
480 \\
388 \\
490 \\
421 \\
478 \\
414 \\
482 \\
439\end{array}$ & $\begin{array}{l}135 \\
125 \\
134 \\
135 \\
136 \\
144 \\
137 \\
145 \\
147 \\
136 \\
134 \\
132 \\
142 \\
149\end{array}$ \\
\hline Females & $\begin{array}{l}1941 \\
1942 \\
1943 \\
1944 \\
1945 \\
1946 \\
1947 \\
1948 \\
1949 \\
1950 \\
1951 \\
1952 \\
1953 \\
1954\end{array}$ & $\begin{array}{l}0 \\
1 \\
1 \\
0 \\
1 \\
1 \\
0 \\
0 \\
1 \\
1 \\
0 \\
1 \\
3 \\
0\end{array}$ & $\begin{array}{r}11 \\
11 \\
7 \\
5 \\
10 \\
15 \\
11 \\
11 \\
15 \\
10 \\
9 \\
11 \\
10 \\
12\end{array}$ & $\begin{array}{l}20 \\
18 \\
25 \\
24 \\
27 \\
27 \\
28 \\
20 \\
26 \\
23 \\
20 \\
12 \\
22 \\
23\end{array}$ & $\begin{array}{l}55 \\
48 \\
54 \\
48 \\
55 \\
52 \\
51 \\
50 \\
45 \\
35 \\
38 \\
36 \\
39 \\
52\end{array}$ & $\begin{array}{l}70 \\
78 \\
86 \\
74 \\
78 \\
87 \\
80 \\
80 \\
77 \\
75 \\
66 \\
66 \\
79 \\
77\end{array}$ & $\begin{array}{l}126 \\
118 \\
112 \\
107 \\
123 \\
145 \\
146 \\
160 \\
144 \\
139 \\
146 \\
134 \\
145 \\
149\end{array}$ & $\begin{array}{l}117 \\
114 \\
117 \\
114 \\
122 \\
146 \\
166 \\
173 \\
165 \\
153 \\
167 \\
165 \\
171 \\
198\end{array}$ & $\begin{array}{r}67 \\
81 \\
66 \\
70 \\
79 \\
92 \\
114 \\
98 \\
138 \\
115 \\
107 \\
98 \\
128 \\
130\end{array}$ & $\begin{array}{l}62 \\
62 \\
63 \\
58 \\
66 \\
75 \\
76 \\
79 \\
75 \\
70 \\
72 \\
68 \\
76 \\
81\end{array}$ \\
\hline
\end{tabular}

Table $\mathrm{X}$ shows that the relative frequencies of different methods of suicide has also changed during recent years. The use of analgesic and soporific drugs has increased and was about four times as common at the end of the period as at the beginning.
This method of suicide is the only one in which the number of females exceeded the number of males. The use of coal gas has steadily increased, the death rates having risen by 50 per cent. for both sexes during the 14 years. The use of other poisons has

TABLE X

DEATH RATES PER MILLION FROM SUICIDE, BY METHOD AND SEX, ENGLAND AND WALES, 1941-1954

\begin{tabular}{|c|c|c|c|c|c|c|c|c|c|c|}
\hline \multirow[b]{2}{*}{ Sex } & \multirow[b]{2}{*}{ Year } & \multicolumn{3}{|c|}{ Poisoning } & \multirow{2}{*}{$\begin{array}{c}\text { Hanging } \\
\text { and } \\
\text { Strangu- } \\
\text { lation }\end{array}$} & \multirow[b]{2}{*}{ Drowning } & \multirow{2}{*}{$\begin{array}{l}\text { Firearms } \\
\text { and } \\
\text { Explosives }\end{array}$} & \multirow{2}{*}{$\begin{array}{l}\text { Cutting } \\
\text { and } \\
\text { Piercing }\end{array}$} & \multirow{2}{*}{$\begin{array}{c}\text { Jumping } \\
\text { from High } \\
\text { Places }\end{array}$} & \multirow[b]{2}{*}{$\begin{array}{l}\text { Other } \\
\text { Methods }\end{array}$} \\
\hline & & $\begin{array}{c}\text { Analgesic } \\
\text { and } \\
\text { Soporific } \\
\text { Substances }\end{array}$ & $\underset{\text { Gas }}{\text { Domestic }}$ & $\begin{array}{l}\text { Other } \\
\text { Poisons }\end{array}$ & & & & & & \\
\hline Males & $\begin{array}{l}1941 \\
1942 \\
1943 \\
1944 \\
1945 \\
1946 \\
1947 \\
1948 \\
1949 \\
1950 \\
1951 \\
1952 \\
1953 \\
1954\end{array}$ & $\begin{array}{r}3 \\
2 \\
2 \\
2 \\
3 \\
3 \\
5 \\
7 \\
7 \\
8 \\
7 \\
11 \\
9 \\
10\end{array}$ & $\begin{array}{l}42 \\
38 \\
41 \\
46 \\
45 \\
46 \\
47 \\
54 \\
53 \\
49 \\
51 \\
52 \\
60 \\
64\end{array}$ & $\begin{array}{l}7 \\
6 \\
7 \\
7 \\
7 \\
7 \\
6 \\
6 \\
6 \\
5 \\
5 \\
5 \\
5 \\
4\end{array}$ & $\begin{array}{l}24 \\
24 \\
27 \\
24 \\
29 \\
32 \\
30 \\
29 \\
31 \\
27 \\
25 \\
25 \\
25 \\
29\end{array}$ & $\begin{array}{l}17 \\
16 \\
18 \\
19 \\
18 \\
18 \\
15 \\
17 \\
17 \\
16 \\
15 \\
13 \\
12 \\
14\end{array}$ & $\begin{array}{r}15 \\
14 \\
14 \\
12 \\
11 \\
11 \\
12 \\
10 \\
11 \\
9 \\
9 \\
8 \\
10 \\
9\end{array}$ & $\begin{array}{r}16 \\
13 \\
15 \\
15 \\
14 \\
15 \\
11 \\
9 \\
11 \\
9 \\
8 \\
7 \\
9 \\
8\end{array}$ & $\begin{array}{l}4 \\
5 \\
4 \\
4 \\
3 \\
4 \\
4 \\
5 \\
4 \\
4 \\
4 \\
3 \\
3 \\
4\end{array}$ & $\begin{array}{r}6 \\
6 \\
5 \\
6 \\
5 \\
7 \\
7 \\
7 \\
6 \\
8 \\
7 \\
7 \\
7 \\
7\end{array}$ \\
\hline Females & $\begin{array}{l}1941 \\
1942 \\
1943 \\
1944 \\
1945 \\
1946 \\
1947 \\
1948 \\
1949 \\
1950 \\
1951 \\
1952 \\
1953 \\
1954\end{array}$ & $\begin{array}{r}3 \\
3 \\
3 \\
3 \\
4 \\
5 \\
6 \\
10 \\
9 \\
11 \\
10 \\
13 \\
11 \\
14\end{array}$ & $\begin{array}{l}28 \\
29 \\
29 \\
28 \\
31 \\
36 \\
39 \\
40 \\
38 \\
33 \\
39 \\
34 \\
41 \\
47\end{array}$ & $\begin{array}{l}7 \\
6 \\
5 \\
5 \\
5 \\
5 \\
5 \\
3 \\
4 \\
4 \\
3 \\
3 \\
3 \\
2\end{array}$ & $\begin{array}{l}6 \\
5 \\
6 \\
5 \\
6 \\
8 \\
7 \\
6 \\
6 \\
6 \\
6 \\
5 \\
6 \\
6\end{array}$ & $\begin{array}{l}11 \\
11 \\
13 \\
11 \\
12 \\
12 \\
11 \\
11 \\
10 \\
10 \\
10 \\
8 \\
9 \\
8\end{array}$ & $\begin{array}{l}1 \\
1 \\
1 \\
1 \\
1 \\
0 \\
1 \\
1 \\
0 \\
0 \\
1 \\
0 \\
0 \\
0\end{array}$ & $\begin{array}{l}2 \\
2 \\
3 \\
2 \\
2 \\
3 \\
2 \\
2 \\
2 \\
2 \\
1 \\
1 \\
1 \\
1\end{array}$ & $\begin{array}{l}2 \\
3 \\
2 \\
2 \\
3 \\
3 \\
3 \\
3 \\
3 \\
2 \\
2 \\
2 \\
2 \\
2\end{array}$ & $\begin{array}{l}3 \\
2 \\
2 \\
2 \\
2 \\
3 \\
2 \\
3 \\
2 \\
2 \\
2 \\
1 \\
1 \\
2\end{array}$ \\
\hline
\end{tabular}


fallen by half. The death rate from hanging has risen slightly for males but has remained fairly constant for females. Other methods of suicidedrowning, firearms, cutting and piercing, jumping from high places-were less frequent at the end than at the beginning of the period.

The distribution of the methods used was quite different for the two sexes, although coal gas poisoning was the most frequent means of suicide for both sexes. The distribution of deaths by method of suicide for 1954 is shown in Table XI. Poisoning by coal gas has been numerically the most important method of suicide for the past 20 years. During this period the number of deaths has increased more rapidly for females than for males. The number of deaths in 1950-54, expressed as a percentage of those in 1930-34, was 113 for males and 148 for females.

TABLE XI

DEATHS FROM SUICIDE, BY SEX

\begin{tabular}{|c|c|c|c|c|}
\hline \multirow{2}{*}{ Method of Suicide } & \multicolumn{2}{|c|}{ Males } & \multicolumn{2}{|c|}{ Females } \\
\hline & $\overline{\text { Number }}$ & $\overline{\text { Percentage }}$ & $\overline{\text { Number }}$ & Percentage \\
\hline $\begin{array}{l}\text { Analgesics and Sopo- } \\
\text { rific Drugs } \\
\text { Domestic Gas }\end{array}$ & $\begin{array}{r}222 \\
1,356 \\
612 \\
290 \\
160 \\
197 \\
341\end{array}$ & $\begin{array}{r}7 \cdot 0 \\
42 \cdot 7 \\
19 \cdot 3 \\
9 \cdot 1 \\
5 \cdot 0 \\
6 \cdot 2 \\
10 \cdot 7\end{array}$ & $\begin{array}{r}312 \\
1,072 \\
128 \\
178 \\
27 \\
6 \\
142\end{array}$ & $\begin{array}{r}16 \cdot 7 \\
57 \cdot 5 \\
6.9 \\
9 \cdot 5 \\
1.4 \\
0.3 \\
7 \cdot 6\end{array}$ \\
\hline All Methods .. & 3,178 & $100 \cdot 0$ & 1,865 & $100 \cdot 0$ \\
\hline
\end{tabular}

The rise in the number of deaths since the introduction of gas for domestic use is shown in Table XII. The trend of the deaths during the war years was different for the two sexes. In 1940-44 the number of suicides in males from coal gas poisoning as a percentage of the number in the preceding quinquennium was 68; the same is true for all methods of suicide. The number of suicides in females in 1940-44 was 82 per cent. of the number in 1935-39, but the number of suicides from coal gas poisoning fell only to 87 per cent. The total

TABLE XII

NUMBER OF SUICIDES BY DOMESTIC GAS POISONING IN ENGLAND AND WALES

\begin{tabular}{c|r|r}
\hline Quinquennium & Males & Females \\
\hline $1890-94$ & 2 & 1 \\
$1895-99$ & 8 & 5 \\
$1900-04$ & 43 & 10 \\
$1905-09$ & 268 & 94 \\
$1910-14$ & 432 & 169 \\
$1915-19$ & 419 & 340 \\
$1920-24$ & 1,529 & 864 \\
$1925-29$ & 3,185 & 1,868 \\
$1930-34$ & 5,174 & 2,983 \\
$1935-39$ & 5,482 & 3,644 \\
$1940-44$ & 3,715 & 3,182 \\
$1945-49$ & 4,681 & 4,081 \\
$1950-54$ & 5,833 & 4,427 \\
\hline
\end{tabular}

number of suicides in 1915-19 as a percentage of those in 1910-14 was 75 for males and 97 for females, but the corresponding percentages for coal gas poisoning were 96 for males and 200 for females.

Deaths from analgesics and soporific drugs were mainly due to two groups of substances: barbituric acid and its derivatives, and aspirin and salicylates. The number of deaths from both types of drug has rapidly increased. In the 10 years following 1940 they produced approximately the same number of deaths, but since 1950 sleeping draughts and tablets have become almost three times as frequent as aspirin. The number of deaths registered in England and Wales from these substances during recent years is shown in Table XIII. The rate of increase during the period was larger in males than in females. For barbituric acid the number of deaths in 1950-54 was 8.4 times the number in $1940-44$ for males and 6.9 times for females. The corresponding ratio for aspirin and salicylates was $4 \cdot 0$ in males and $2 \cdot 3$ in females.

TABLE XIII

DEATHS FROM DRUGS, BY SEX

\begin{tabular}{c|r|r|rr}
\hline \multirow{2}{*}{ Quinquennium } & \multicolumn{2}{|c|}{$\begin{array}{c}\text { Barbituric Acid and } \\
\text { Derivatives }\end{array}$} & \multicolumn{2}{c}{ Aspirin and Salicylates } \\
\cline { 2 - 5 } & Males & Females & Males & Females \\
\hline $1940-44$ & 79 & 132 & 64 & 154 \\
$1945-49$ & 218 & 345 & 189 & 328 \\
$1950-54$ & 664 & 907 & 256 & 357 \\
\hline Total & 961 & 1,384 & 509 & 839 \\
\hline
\end{tabular}

\section{HoMICIDE}

The death rate from homicide (Table XIV) has decreased steadily during the past 100 years although the improvement has been slow during the past 15 years. In the earlier years the death rate in males

TABLE XIV

HOMICIDE, DEATH RATES PER MILLION, BY SEX

\begin{tabular}{c|c|c}
\hline Period & Males & Females \\
\hline $1863-70$ & 26 & 15 \\
$1871-80$ & 19 & 12 \\
$1881-90$ & 15 & 10 \\
$1891-00$ & 12 & 9 \\
$1901-10$ & 10 & 9 \\
$1911-20$ & 8 & 8 \\
$1921-30$ & 7 & 6 \\
$1931-40$ & 6 & 6 \\
1941 & 5 & 5 \\
1942 & 7 & 5 \\
1943 & 6 & 5 \\
1944 & 5 & 6 \\
1945 & 8 & 5 \\
1946 & 5 & 6 \\
1947 & 5 & 5 \\
1948 & 6 & 5 \\
1949 & 4 & 5 \\
1950 & 5 & 4 \\
1951 & 5 & 4 \\
1952 & 5 & 5 \\
1953 & 5 & \\
1954 & 5 & \\
\hline
\end{tabular}


was 50 per cent. greater than that in females. A greater improvement has occurred in males than in females; the chance of being a victim of murder or manslaughter is now about equal for the two sexes.

The worst recent record was that of 1945; the
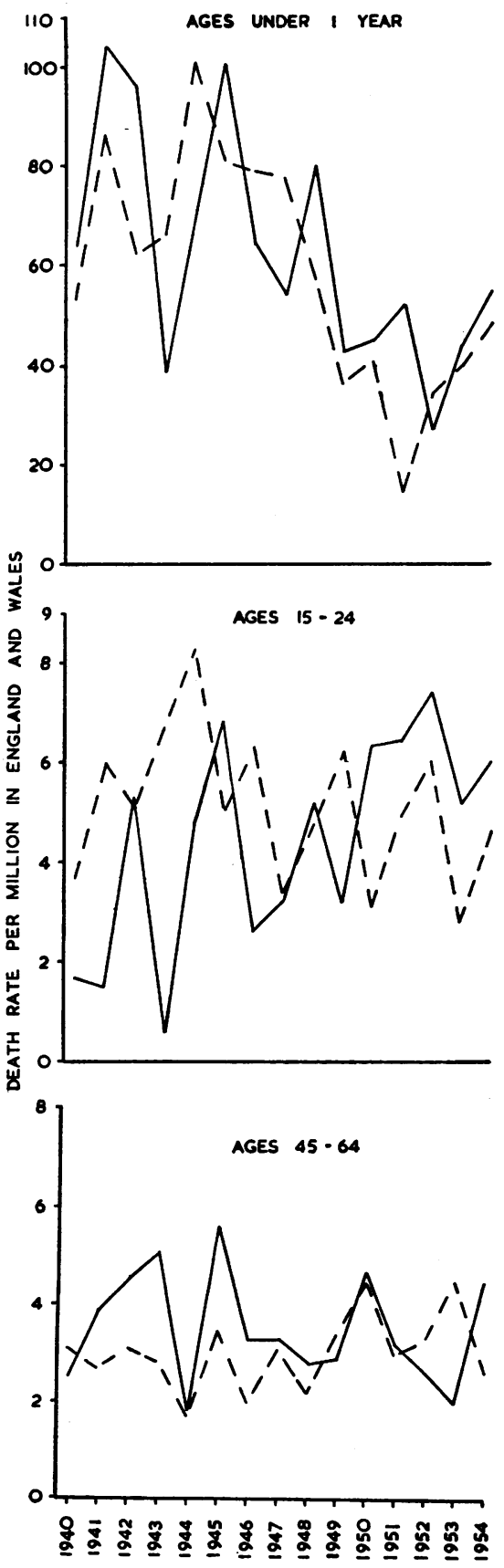

deaths rose from 68 in 1944 to 121 in 1945 in males, and from 103 to 131 in females. The deaths in males showed an increase in each age group; in females, however, the deaths at ages under 1 year and at ages 15-24 were each 10 less than in 1944 (Figure).
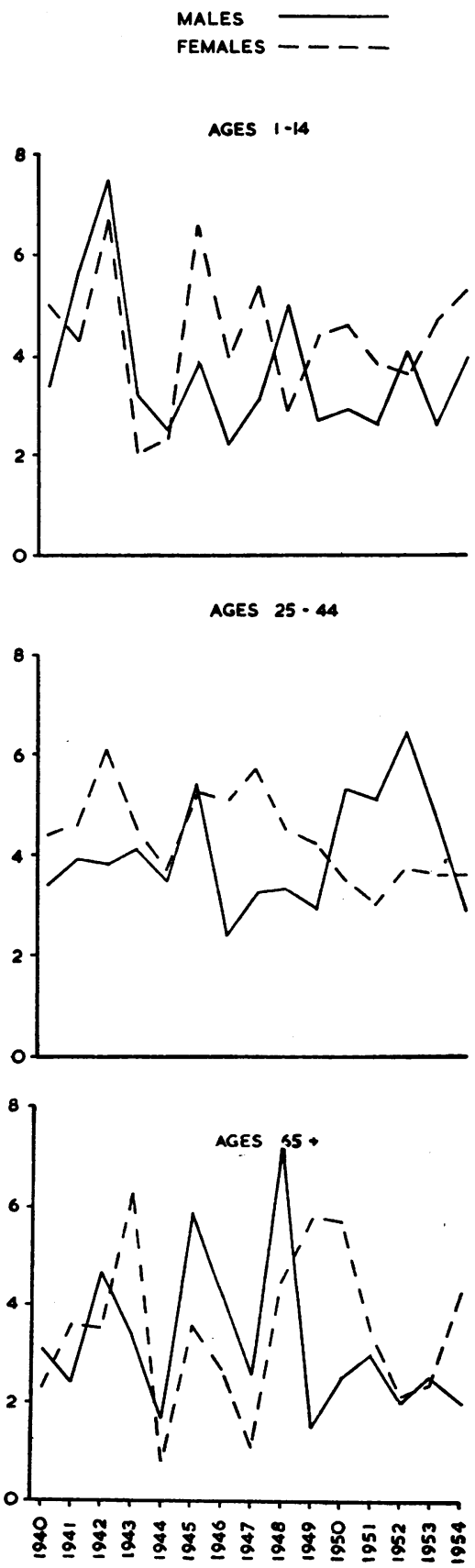
TABLE XV

PERCENTAGE DISTRIBUTION OF DEATHS FROM HOMICIDE, BY AGE AND SEX

\begin{tabular}{|c|c|c|c|c|c|c|c|c|c|c|c|}
\hline \multirow{2}{*}{ Sex } & \multirow{2}{*}{ Quinquennium } & \multicolumn{9}{|c|}{ Age (yrs) } & \multirow{2}{*}{$\begin{array}{l}\text { No. of } \\
\text { Deaths }\end{array}$} \\
\hline & & Under 1 & $1-$ & $5-$ & $15-$ & $25-$ & $45-$ & $65-$ & $75-$ & Total & \\
\hline Males & $\begin{array}{l}1940-44 \\
1945-49 \\
1950-54\end{array}$ & $\begin{array}{l}27 \cdot 3 \\
28 \cdot 1 \\
15 \cdot 8\end{array}$ & $\begin{array}{r}10 \cdot 7 \\
7 \cdot 3 \\
6 \cdot 4\end{array}$ & $\begin{array}{r}10 \cdot 7 \\
8 \cdot 2 \\
9 \cdot 0\end{array}$ & $\begin{array}{r}6 \cdot 2 \\
9 \cdot 4 \\
15 \cdot 2\end{array}$ & $\begin{array}{l}20.4 \\
20.6 \\
31.4\end{array}$ & $\begin{array}{l}18 \cdot 5 \\
17 \cdot 6 \\
17 \cdot 4\end{array}$ & $\begin{array}{l}4 \cdot 8 \\
6 \cdot 0 \\
3 \cdot 9\end{array}$ & $\begin{array}{l}1 \cdot 4 \\
2 \cdot 8 \\
1 \cdot 0\end{array}$ & $\begin{array}{l}100 \\
100 \\
100\end{array}$ & $\begin{array}{l}421 \\
466 \\
488\end{array}$ \\
\hline Females & $\begin{array}{l}1940-44 \\
1945-49 \\
1950-54\end{array}$ & $\begin{array}{l}20 \cdot 3 \\
20 \cdot 9 \\
12 \cdot 2\end{array}$ & $\begin{array}{r}6 \cdot 9 \\
8 \cdot 7 \\
10 \cdot 5\end{array}$ & $\begin{array}{l}7 \cdot 8 \\
7 \cdot 5 \\
9 \cdot 7\end{array}$ & $\begin{array}{l}16 \cdot 8 \\
13 \cdot 0 \\
12 \cdot 6\end{array}$ & $\begin{array}{l}28 \cdot 5 \\
28 \cdot 3 \\
23 \cdot 3\end{array}$ & $\begin{array}{l}12 \cdot 8 \\
13 \cdot 4 \\
21 \cdot 0\end{array}$ & $\begin{array}{l}4 \cdot 6 \\
5 \cdot 5 \\
6 \cdot 6\end{array}$ & $\begin{array}{l}2 \cdot 4 \\
2 \cdot 6 \\
4 \cdot 1\end{array}$ & $\begin{array}{l}100 \\
100 \\
100\end{array}$ & $\begin{array}{l}548 \\
583 \\
485\end{array}$ \\
\hline
\end{tabular}

The percentage distribution of deaths by age for the last three quinquennial periods is shown in Table XV. The distributions of deaths in 1940-44 and 1945-49 were very similar. The most striking feature of these years is that almost one-quarter of the deaths were those of infants; in all, 479 babies were killed. The risk of being killed in adult life was differently distributed in the sexes, females being killed at younger ages than males. In 1950-54, the homicide rate underwent considerable changes. A large fall occurred in the death rate under age 1: the actual number of male infants killed fell from 131 in $1945-49$ to 77 in 1950-54, and the number of female infants killed fell from 122 to 59 . The age distribution of the sexes also changed; in the last quinquennium the females were killed at an older average age than the males. Despite the large fall in the total number of deaths in females, the number of females killed at ages $45-54$ rose from 78 in $1945-49$ to 102 in 1950-54. The number of deaths in males at ages 15-24 rose from 44 in 1945-49 to 94 in 1950-54; at ages 25-44 they rose from 96 to 153 .

\section{Regional Distribution}

The death rates from motor accidents and from all other accidents in 1950-54 by age and sex are shown in Table XVI (opposite). They are classified by region and by density of population.

\section{(1) Motor Accidents}

(a) Regional Classification.-In males the largest regional differences were in the age group under 5 years. The lowest death rates in both sexes in this group were in the three regions which include London and the South East, the East, and the South; the highest were in the North, North West, and Wales I. The rates in the former regions were less than half those in the latter. At older ages the position is different. In both sexes the rate for London and the South East remained relatively low until old age. In males, however, mortality after childhood was relatively high in the South and East; this tendency appears also in the females but the rates are less regular. At ages 15-24 and 25-44 the highest death rate in males was in Wales II; this region, however, had the lowest death rate but one in the age group 45-64.

(b) Classification by Population Density.-In males, the death rates at ages 15-64 increased with decreasing population density and the two lowest age groups showed the same tendency. The difference between the mortality in the rural and urban areas was largest at ages 15-24 and 25-44, the rural rate being almost twice that of the lowest urban rate in these age groups. In females also the death rate showed the same tendency to increase with decreasing population density, but with more irregularity up to age 64; after that age the trend was reversed.

\section{(2) All Other Accidents}

(a) Regional Classification.-In both sexes, at ages under 5 years, the lowest death rates were in London and the South East, and the South West, and the highest were in the two regions of Wales. In both sexes also, at ages over 5 years, low rates were found in London and the South East, and in the Midland, and Southern regions. In males, at ages over 5 years, the highest rates were in Wales and the North; in females, they were in the East and West Ridings of Yorkshire and in Wales II.

(b) Classification by Population Density.-In males, the death rates increased with decreasing population density up to age 65 . In this respect, motor accidents and all other accidents are similar. The resemblance is particularly noteworthy at ages $15-24$ and $25-44$, where there is a large excess of rural over urban mortality in both cases. In females no regular pattern can be discerned after infancy, and the death rate in rural areas was relatively high up to middle age.

The regional distribution of suicides by age and sex is shown in Table XVII (opposite). The relative positions of the regions vary in each age group. The mortality was consistently high in each age group in 
TABLE XVI

REGIONAL DISTRIBUTION OF ACCIDENTS, BY AGE AND SEX, IN ENGLAND AND WALES, 1950-54, DEATH RATES PER MILLION

\begin{tabular}{|c|c|c|c|c|c|c|c|c|c|c|c|c|c|c|c|c|c|}
\hline \multirow{2}{*}{$\begin{array}{c}\text { Type } \\
\text { of } \\
\text { Accident }\end{array}$} & \multirow[b]{2}{*}{ Region } & \multicolumn{8}{|c|}{ Males } & \multicolumn{8}{|c|}{ Females } \\
\hline & & $\underset{5}{\text { Under }}$ & $5-$ & $15-$ & $25-$ & 45- & $65-$ & $\begin{array}{c}75 \\
\text { and } \\
\text { Over }\end{array}$ & $\begin{array}{c}\text { All } \\
\text { Ages }\end{array}$ & $\underset{5}{\text { Under }}$ & $5-$ & $15-$ & $25-$ & $45-$ & $65-$ & $\begin{array}{c}75 \\
\text { and } \\
\text { Over }\end{array}$ & $\begin{array}{c}\text { All } \\
\text { Ages }\end{array}$ \\
\hline \multirow[t]{2}{*}{$\begin{array}{l}\text { Motor } \\
\text { Vehicle }\end{array}$} & 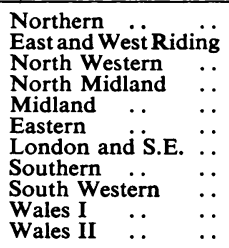 & $\begin{array}{r}176 \\
98 \\
134 \\
111 \\
92 \\
58 \\
46 \\
64 \\
76 \\
138 \\
68\end{array}$ & $\begin{array}{r}102 \\
86 \\
97 \\
106 \\
90 \\
88 \\
80 \\
70 \\
92 \\
91 \\
73\end{array}$ & $\begin{array}{l}186 \\
234 \\
211 \\
267 \\
267 \\
293 \\
206 \\
292 \\
309 \\
190 \\
357\end{array}$ & $\begin{array}{l}138 \\
131 \\
127 \\
151 \\
163 \\
167 \\
108 \\
183 \\
147 \\
140 \\
206\end{array}$ & $\begin{array}{l}134 \\
136 \\
133 \\
147 \\
139 \\
152 \\
110 \\
115 \\
144 \\
131 \\
124\end{array}$ & $\begin{array}{l}221 \\
254 \\
227 \\
242 \\
332 \\
254 \\
214 \\
292 \\
209 \\
180 \\
243\end{array}$ & $\begin{array}{l}545 \\
458 \\
628 \\
359 \\
593 \\
407 \\
562 \\
398 \\
254 \\
462 \\
388\end{array}$ & $\begin{array}{l}158 \\
152 \\
154 \\
167 \\
174 \\
174 \\
131 \\
183 \\
164 \\
155 \\
185\end{array}$ & $\begin{array}{l}72 \\
50 \\
74 \\
65 \\
62 \\
48 \\
38 \\
42 \\
54 \\
70 \\
57\end{array}$ & $\begin{array}{l}49 \\
37 \\
44 \\
41 \\
49 \\
37 \\
31 \\
38 \\
33 \\
54 \\
34\end{array}$ & $\begin{array}{l}31 \\
29 \\
24 \\
35 \\
35 \\
49 \\
36 \\
57 \\
44 \\
45 \\
48\end{array}$ & $\begin{array}{l}17 \\
18 \\
22 \\
17 \\
27 \\
24 \\
18 \\
21 \\
12 \\
19 \\
16\end{array}$ & \begin{tabular}{l|}
39 \\
45 \\
42 \\
36 \\
49 \\
47 \\
40 \\
32 \\
44 \\
34 \\
29
\end{tabular} & $\begin{array}{r}87 \\
95 \\
107 \\
82 \\
124 \\
83 \\
102 \\
89 \\
84 \\
93 \\
95\end{array}$ & $\begin{array}{r}131 \\
193 \\
236 \\
190 \\
201 \\
157 \\
245 \\
142 \\
134 \\
162 \\
80\end{array}$ & $\begin{array}{l}43 \\
44 \\
50 \\
44 \\
53 \\
48 \\
47 \\
45 \\
43 \\
46 \\
39\end{array}$ \\
\hline & 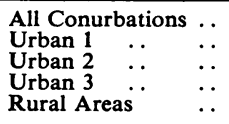 & $\begin{array}{l}86 \\
96 \\
97 \\
95 \\
98\end{array}$ & $\begin{array}{r}82 \\
87 \\
100 \\
83 \\
105\end{array}$ & $\begin{array}{l}185 \\
185 \\
205 \\
246 \\
357\end{array}$ & $\begin{array}{l}112 \\
117 \\
125 \\
137 \\
216\end{array}$ & $\begin{array}{l}115 \\
113 \\
118 \\
129 \\
191\end{array}$ & $\begin{array}{l}229 \\
263 \\
243 \\
209 \\
276\end{array}$ & $\begin{array}{l}617 \\
455 \\
481 \\
432 \\
385\end{array}$ & $\begin{array}{l}134 \\
136 \\
146 \\
151 \\
217\end{array}$ & $\begin{array}{l}51 \\
62 \\
65 \\
56 \\
58\end{array}$ & $\begin{array}{l}35 \\
40 \\
38 \\
42 \\
45\end{array}$ & $\begin{array}{l}33 \\
43 \\
24 \\
33 \\
48\end{array}$ & $\begin{array}{l}19 \\
16 \\
16 \\
17 \\
27\end{array}$ & $\begin{array}{l}44 \\
40 \\
39 \\
30 \\
50\end{array}$ & $\begin{array}{r}112 \\
107 \\
89 \\
84 \\
81\end{array}$ & $\begin{array}{l}259 \\
190 \\
166 \\
159 \\
136\end{array}$ & $\begin{array}{l}49 \\
47 \\
43 \\
41 \\
50\end{array}$ \\
\hline \multirow[t]{2}{*}{$\begin{array}{l}\text { All } \\
\text { Others }\end{array}$} & 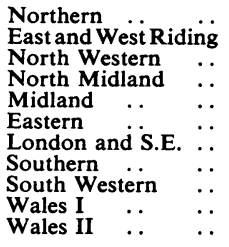 & $\begin{array}{l}415 \\
343 \\
391 \\
340 \\
380 \\
344 \\
248 \\
352 \\
335 \\
464 \\
418\end{array}$ & $\begin{array}{r}116 \\
98 \\
131 \\
96 \\
108 \\
95 \\
80 \\
81 \\
107 \\
120 \\
131\end{array}$ & $\begin{array}{l}285 \\
192 \\
168 \\
245 \\
153 \\
265 \\
163 \\
184 \\
206 \\
262 \\
283\end{array}$ & $\begin{array}{l}328 \\
195 \\
170 \\
234 \\
134 \\
192 \\
133 \\
158 \\
207 \\
357 \\
265\end{array}$ & $\begin{array}{l}435 \\
288 \\
268 \\
294 \\
225 \\
207 \\
203 \\
203 \\
256 \\
470 \\
354\end{array}$ & $\begin{array}{l}589 \\
594 \\
516 \\
467 \\
511 \\
419 \\
427 \\
384 \\
443 \\
680 \\
456\end{array}$ & $\begin{array}{l}2,077 \\
2,492 \\
2,058 \\
1,589 \\
1,927 \\
1,615 \\
1,682 \\
1,507 \\
1,443 \\
1,769 \\
1,612\end{array}$ & $\begin{array}{l}385 \\
303 \\
279 \\
293 \\
241 \\
269 \\
220 \\
236 \\
275 \\
407 \\
345\end{array}$ & $\begin{array}{l}310 \\
279 \\
291 \\
249 \\
264 \\
266 \\
190 \\
240 \\
187 \\
322 \\
414\end{array}$ & $\begin{array}{l}41 \\
37 \\
42 \\
32 \\
34 \\
33 \\
27 \\
24 \\
41 \\
49 \\
30\end{array}$ & $\begin{array}{l}22 \\
28 \\
27 \\
21 \\
18 \\
51 \\
26 \\
24 \\
33 \\
27 \\
26\end{array}$ & $\begin{array}{l}31 \\
29 \\
30 \\
25 \\
25 \\
41 \\
32 \\
27 \\
26 \\
25 \\
35\end{array}$ & \begin{tabular}{r|}
92 \\
93 \\
90 \\
97 \\
83 \\
87 \\
87 \\
77 \\
88 \\
94 \\
110
\end{tabular} & $\begin{array}{l}415 \\
504 \\
437 \\
296 \\
429 \\
386 \\
350 \\
328 \\
302 \\
420 \\
341\end{array}$ & $\begin{array}{l}3,021 \\
3,225 \\
2,687 \\
2,439 \\
2,700 \\
2,366 \\
2,130 \\
2,346 \\
1,973 \\
2,671 \\
2,280\end{array}$ & $\begin{array}{l}205 \\
228 \\
204 \\
190 \\
188 \\
221 \\
184 \\
205 \\
193 \\
193 \\
227\end{array}$ \\
\hline & 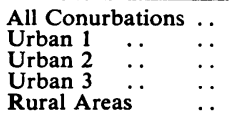 & $\begin{array}{l}305 \\
315 \\
343 \\
365 \\
419\end{array}$ & $\begin{array}{r}97 \\
104 \\
101 \\
106 \\
105\end{array}$ & $\begin{array}{l}150 \\
168 \\
187 \\
187 \\
298\end{array}$ & $\begin{array}{l}145 \\
153 \\
192 \\
211 \\
274\end{array}$ & $\begin{array}{l}229 \\
243 \\
262 \\
302 \\
312\end{array}$ & $\begin{array}{l}498 \\
521 \\
456 \\
516 \\
428\end{array}$ & $\begin{array}{l}1,960 \\
1,937 \\
2,045 \\
1,729 \\
1,511\end{array}$ & $\begin{array}{l}240 \\
256 \\
281 \\
298 \\
325\end{array}$ & $\begin{array}{l}224 \\
229 \\
285 \\
286 \\
278\end{array}$ & $\begin{array}{l}33 \\
39 \\
31 \\
35 \\
35\end{array}$ & $\begin{array}{l}23 \\
23 \\
41 \\
25 \\
35\end{array}$ & $\begin{array}{l}31 \\
26 \\
28 \\
31 \\
31\end{array}$ & $\begin{array}{l}89 \\
81 \\
96 \\
97 \\
81\end{array}$ & $\begin{array}{l}410 \\
397 \\
403 \\
411 \\
324\end{array}$ & $\begin{array}{l}2,436 \\
2,633 \\
2,574 \\
2,507 \\
2,259\end{array}$ & $\begin{array}{l}186 \\
196 \\
223 \\
218 \\
195\end{array}$ \\
\hline
\end{tabular}

Urban 1 = Areas with populations of 100,000 and over.

Urban $3=$ Areas with populations of under 50,000.

Urban 2 = Areas with population of 50,000 and under 100,000 .

TABLE XVII

REGIONAL DISTRIBUTION OF SUICIDES, BY AGE AND SEX, ENGLAND AND WALES 1950-54. DEATH RATES PER MILLION

\begin{tabular}{|c|c|c|c|c|c|c|c|c|c|c|c|c|c|}
\hline \multirow{2}{*}{\multicolumn{2}{|c|}{ Region }} & \multicolumn{6}{|c|}{ Males } & \multicolumn{6}{|c|}{ Females } \\
\hline & & $15-$ & $25-$ & $45-$ & $65-$ & $\begin{array}{l}75 \text { and } \\
\text { Over }\end{array}$ & $\begin{array}{l}15 \text { and } \\
\text { Over }\end{array}$ & $15-$ & $25-$ & 45 & 65 & $\begin{array}{c}75 \text { and } \\
\text { Over }\end{array}$ & $\begin{array}{l}15 \text { and } \\
\text { Over }\end{array}$ \\
\hline 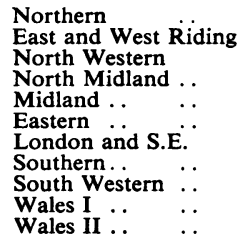 & $\begin{array}{l}\ldots \\
\ldots \\
\cdots \\
\cdots \\
\cdots \\
\cdots \\
\cdots\end{array}$ & $\begin{array}{l}41 \\
48 \\
44 \\
31 \\
43 \\
44 \\
51 \\
50 \\
40 \\
31 \\
41\end{array}$ & $\begin{array}{r}109 \\
104 \\
108 \\
100 \\
97 \\
99 \\
108 \\
104 \\
117 \\
73 \\
108\end{array}$ & $\begin{array}{l}272 \\
274 \\
279 \\
280 \\
260 \\
273 \\
251 \\
232 \\
253 \\
214 \\
201\end{array}$ & $\begin{array}{l}399 \\
386 \\
449 \\
441 \\
500 \\
383 \\
400 \\
395 \\
402 \\
326 \\
331\end{array}$ & $\begin{array}{l}416 \\
606 \\
543 \\
423 \\
513 \\
389 \\
474 \\
353 \\
288 \\
292 \\
328\end{array}$ & $\begin{array}{l}182 \\
192 \\
197 \\
185 \\
181 \\
180 \\
183 \\
164 \\
177 \\
142 \\
158\end{array}$ & $\begin{array}{l}13 \\
14 \\
18 \\
8 \\
18 \\
11 \\
18 \\
14 \\
14 \\
18 \\
22\end{array}$ & $\begin{array}{l}49 \\
49 \\
53 \\
58 \\
62 \\
56 \\
63 \\
58 \\
55 \\
50 \\
35\end{array}$ & $\begin{array}{l}111 \\
147 \\
148 \\
144 \\
160 \\
150 \\
145 \\
141 \\
137 \\
122 \\
117\end{array}$ & $\begin{array}{l}111 \\
185 \\
200 \\
183 \\
197 \\
160 \\
173 \\
170 \\
170 \\
81 \\
101\end{array}$ & $\begin{array}{r}67 \\
88 \\
155 \\
92 \\
154 \\
107 \\
121 \\
128 \\
98 \\
120 \\
40\end{array}$ & $\begin{array}{r}69 \\
92 \\
100 \\
91 \\
102 \\
93 \\
97 \\
94 \\
91 \\
74 \\
68\end{array}$ \\
\hline $\begin{array}{ll}\text { All Conurbations } \\
\text { Urban 1 } \ldots & . \\
\text { Urban 2 } \ldots & \ldots \\
\text { Urban 3 } \ldots & \ldots \\
\text { Rural Areas } & \ldots\end{array}$ & $\begin{array}{l}\ldots \\
\cdots \\
\cdots\end{array}$ & $\begin{array}{l}47 \\
54 \\
39 \\
41 \\
39\end{array}$ & $\begin{array}{r}109 \\
106 \\
104 \\
99 \\
98\end{array}$ & $\begin{array}{l}259 \\
258 \\
278 \\
267 \\
248\end{array}$ & $\begin{array}{l}430 \\
431 \\
485 \\
406 \\
350\end{array}$ & $\begin{array}{l}542 \\
479 \\
523 \\
429 \\
292\end{array}$ & $\begin{array}{l}187 \\
186 \\
197 \\
185 \\
160\end{array}$ & $\begin{array}{r}17 \\
18 \\
8 \\
17 \\
13\end{array}$ & $\begin{array}{l}62 \\
63 \\
51 \\
55 \\
44\end{array}$ & $\begin{array}{l}146 \\
179 \\
164 \\
141 \\
103\end{array}$ & $\begin{array}{l}186 \\
204 \\
201 \\
165 \\
111\end{array}$ & $\begin{array}{r}130 \\
152 \\
133 \\
109 \\
68\end{array}$ & $\begin{array}{r}97 \\
112 \\
102 \\
92 \\
66\end{array}$ \\
\hline
\end{tabular}

Urban 1 = Areas with population of 100,000 and over

Urban 2 = Areas with population of 50,000 and under 100,000 .

Urban $3=$ Areas with population of under 50,000 .

the North West region, and was low in both regions of Wales. At ages 75 and over, in both sexes, the lowest regional rate was less than half the highest regional rate. In both sexes and in each age group (with the exception of females aged 15-24), the suicide rate was lower in rural than in urban areas. 


\section{Seasonal Distribution}

The seasonal distribution of all violent deaths for the past 15 years is shown in Table XVIII. There is a winter maximum and a summer minimum. The difference between winter and summer was more pronounced in the quinquennium including the war years than in the two following quinquennia. This seasonal analysis gives only a composite picture. An examination of separate causes is a necessary preliminary to any search for explanation.

Suicide.-The suicide rate is highest in summer. Explanations of the fall in the number of suicides during the more gloomy weather require more than statistical data alone. It is interesting to recall that low rates were recorded during the two world wars, but it is the merest speculation to compare psychological and meteorological gloom.

Motor Vehicles.-The maximum is in winter. This is, perhaps, a little surprising, since traffic is much increased in summer, especially at week ends by private cars. There must, it seems, be some connexion here with the more dangerous driving conditions which prevail in the winter months.

Accidental Falls.-There is a high peak in winter. Deaths from falls at home or in residential institutions made up 74 per cent. of all deaths from falls during 1950-54; furthermore, 80 per cent. of deaths from falls during 1950-54 occurred in the age group 65 and over. Thus the weather cannot provide a direct explanation. Nevertheless, more time is spent indoors in winter and it may be that among old people there is an increased risk of death, in cold weather, from complications following an accident.

Other Accidents.-These also show a summer minimum and winter maximum. The seasonal variation in the last two quinquennia was not as large as that found for motor vehicles and accidental falls.

\section{SUMMARY}

During the 15 years 1940-54, changes occurred in the age and sex distribution of violent deaths. Death rates in childhood declined continuously, the rate in 1954 being only one-half that of 15 years earlier. At ages over 15 years the death rate fell to a minimum in the late 1940s; it rose subsequently but the rate at the end of the period was still below that at the beginning.

In males, the smallest improvement in the death rate from accidents was at ages 15-19 and 20-24. The death rate from motor accidents has declined in each age group in both sexes, except among males aged 15-24, where the death rate in 1954 was slightly above that of 15 years earlier. Deaths of motor cyclists and their passengers figure prominently in these age groups.

A large improvement occurred in the death rates from falls during the period, especially in childhood. In males the death rate was much larger than in females until age 54; at ages 65-70 and 75 and over, the chances of a fatal fall was greater for females. More males than females below the age of 45 had a fatal fall at home; after this age the females were in excess. The death rate from burns was larger among females than males, particularly in childhood and old age.

TABLE XVIII

SEASONAL DISTRIBUTION OF DEATHS, ENGLAND AND WALES, 1940-54

(Average number of deaths per day expressed as a percentage of the annual average)

\begin{tabular}{|c|c|c|c|c|c|c|c|c|c|c|c|c|c|c|}
\hline \multirow{2}{*}{$\begin{array}{l}\text { Type of } \\
\text { Violence }\end{array}$} & \multirow{2}{*}{$\underset{\text { quennium }}{\text { Quin- }}$} & \multicolumn{12}{|c|}{ Month } & \multirow[b]{2}{*}{ Total } \\
\hline & & Jan. & Feb. & Mar. & Apr. & May & Jun. & Jul. & Aug. & Sept. & Oct. & Nov. & Dec. & \\
\hline $\begin{array}{c}\text { All except } \\
\text { War } \\
\text { Casualties }\end{array}$ & $\begin{array}{l}1940-44 \\
1945-49 \\
1950-54\end{array}$ & $\begin{array}{l}121 \\
108 \\
108\end{array}$ & $\begin{array}{l}112 \\
106 \\
108\end{array}$ & $\begin{array}{l}106 \\
104 \\
101\end{array}$ & $\begin{array}{r}98 \\
100 \\
102\end{array}$ & $\begin{array}{l}92 \\
97 \\
95\end{array}$ & $\begin{array}{l}93 \\
97 \\
95\end{array}$ & $\begin{array}{r}89 \\
102 \\
97\end{array}$ & $\begin{array}{l}88 \\
95 \\
95\end{array}$ & $\begin{array}{l}90 \\
93 \\
93\end{array}$ & $\begin{array}{l}94 \\
93 \\
98\end{array}$ & $\begin{array}{r}101 \\
100 \\
99\end{array}$ & $\begin{array}{l}117 \\
106 \\
110\end{array}$ & $\begin{array}{l}100 \\
100 \\
100\end{array}$ \\
\hline Suicide & $\begin{array}{l}1940-44 \\
1945-49 \\
1950-54\end{array}$ & $\begin{array}{l}91 \\
93 \\
97\end{array}$ & $\begin{array}{r}104 \\
93 \\
100\end{array}$ & $\begin{array}{l}112 \\
107 \\
105\end{array}$ & $\begin{array}{l}110 \\
111 \\
113\end{array}$ & $\begin{array}{l}106 \\
107 \\
110\end{array}$ & $\begin{array}{l}117 \\
111 \\
109\end{array}$ & $\begin{array}{r}106 \\
107 \\
99\end{array}$ & $\begin{array}{l}95 \\
93 \\
96\end{array}$ & $\begin{array}{l}93 \\
96 \\
91\end{array}$ & $\begin{array}{l}89 \\
89 \\
95\end{array}$ & $\begin{array}{l}84 \\
98 \\
92\end{array}$ & $\begin{array}{l}93 \\
95 \\
93\end{array}$ & $\begin{array}{l}100 \\
100 \\
100\end{array}$ \\
\hline $\begin{array}{l}\text { Motor } \\
\text { Vehicle }\end{array}$ & $\begin{array}{l}1940-44 \\
1945-49 \\
1950-54\end{array}$ & $\begin{array}{r}109 \\
95 \\
93\end{array}$ & $\begin{array}{l}96 \\
86 \\
82\end{array}$ & $\begin{array}{l}96 \\
77 \\
83\end{array}$ & $\begin{array}{l}87 \\
89 \\
89\end{array}$ & $\begin{array}{l}80 \\
92 \\
93\end{array}$ & $\begin{array}{l}78 \\
96 \\
94\end{array}$ & $\begin{array}{r}80 \\
103 \\
103\end{array}$ & $\begin{array}{r}88 \\
102 \\
105\end{array}$ & $\begin{array}{l}101 \\
103 \\
104\end{array}$ & $\begin{array}{l}112 \\
113 \\
112\end{array}$ & $\begin{array}{l}127 \\
119 \\
117\end{array}$ & $\begin{array}{l}147 \\
124 \\
125\end{array}$ & $\begin{array}{l}100 \\
100 \\
100\end{array}$ \\
\hline Falls & $\begin{array}{l}1940-44 \\
1945-49 \\
1950-54\end{array}$ & $\begin{array}{l}133 \\
122 \\
120\end{array}$ & $\begin{array}{l}129 \\
127 \\
123\end{array}$ & $\begin{array}{l}109 \\
114 \\
106\end{array}$ & $\begin{array}{r}102 \\
97 \\
95\end{array}$ & $\begin{array}{l}90 \\
94 \\
87\end{array}$ & $\begin{array}{l}81 \\
88 \\
88\end{array}$ & $\begin{array}{l}79 \\
88 \\
88\end{array}$ & $\begin{array}{l}83 \\
85 \\
87\end{array}$ & $\begin{array}{l}89 \\
90 \\
93\end{array}$ & $\begin{array}{l}91 \\
87 \\
99\end{array}$ & $\begin{array}{l}99 \\
97 \\
99\end{array}$ & $\begin{array}{l}115 \\
112 \\
117\end{array}$ & $\begin{array}{l}100 \\
100 \\
100\end{array}$ \\
\hline $\begin{array}{c}\text { Other } \\
\text { Accidents }\end{array}$ & $\begin{array}{l}1940-44 \\
1945-49 \\
1950-54\end{array}$ & $\begin{array}{l}135 \\
115 \\
116\end{array}$ & $\begin{array}{l}115 \\
114 \\
122\end{array}$ & $\begin{array}{l}107 \\
111 \\
106\end{array}$ & $\begin{array}{r}97 \\
99 \\
106\end{array}$ & $\begin{array}{l}94 \\
95 \\
92\end{array}$ & $\begin{array}{l}97 \\
93 \\
92\end{array}$ & $\begin{array}{r}92 \\
105 \\
98\end{array}$ & $\begin{array}{r}87 \\
100 \\
94\end{array}$ & $\begin{array}{l}84 \\
87 \\
87\end{array}$ & $\begin{array}{l}88 \\
87 \\
90\end{array}$ & $\begin{array}{l}94 \\
93 \\
91\end{array}$ & $\begin{array}{l}110 \\
100 \\
107\end{array}$ & $\begin{array}{l}100 \\
100 \\
100\end{array}$ \\
\hline
\end{tabular}


There was considerable variation in the death rate from accidents between different regions and between different areas of population density. The rate decreased with increasing population up to age 64 . At ages 15-44, the death rate from motor vehicle accidents in rural areas was twice that in urban areas. In old age the death rate from motor accidents was largest in the cities and the lowest in rural areas.

At ages over 45, the suicide rate declined during the war but has risen since 1945. The rise has been greatest among the older women, where the rate in 1954 was almost double that of earlier years. Analgesics and soporific drugs have become a numerically important method of suicide, the only one in which the number of deaths in females exceeded those in males; the use of these drugs, however, is increasing faster among men than among women. Domestic gas is still somewhat more frequently employed as a means of suicide. The death rate from hanging has remained fairly constant during the period, and the more disfiguring forms of suicide have become less frequent.
In the first 10 years, the ratio of female to male victims of homicide was five to four; in 1950-54 the rate in females declined and the sex ratio became approximately unity. A large decrease in the number of homicides under 1 year of age was recorded in $1950-54$; in the same period increases were recorded for females at ages 45-54 and males at ages 15-44.

The trend of violent deaths suggests that the number of fatal accidents among pre-school children could be considerably reduced by better supervision on the part of adults. The very large accident rate at home among the elderly could also be reduced since many of these fatalities were the result of a fall on the same level, such as might be due, for example, to polished floors or uneven floor covering. The rising rate of suicide among women over age 65 could be a reflection of modern social conditions.

I am indebted to Miss B. Hafner and Miss W. Williams for most of the rather laborious computations.

REFERENCE

Swinscow, D. (1953). Arch. Dis. Childh., 28, 26. 